\title{
研究 $\mathrm{LiNbO}_{8}$ 単結晶のラッピング特性*
}

\author{
野田寿一** 井田一郎** \\ Lapping Characteristics of Lithium Niobate \\ Single Crystals
}

Juichi NoDA, Ichiro IDA

\begin{abstract}
This paper deals with the hardness and lapping characteristics of $\mathrm{LiNbO}_{3}$ crystals used for electro-optic elements, comparing with those of lead glass and quartz. The results obtained are as follows: (1) The anisotropy in knoop hardness is marked between (0001) and (1100) surfaces of $\mathrm{LiNbO}_{3}$, causing the strong influences on lapping quantity and surface roughness and the weak one on lapping force. (2) As the increase in diameters of abrasive grains, the anisotropy is emphasized in lapping characteristics. (3) The largest lapping quantity is obtained from a (0001) surface, while the worst roughness from lead glass. The former is governed mainly by the cleavage fracture in $\mathrm{LiNbO}_{3}$, whereas the latter by the fracture in glass. The lapping characteristics of a (1100) surface exhibits the intermediate between lead glass and quartz. (4) The friable character of silicon carbide abrasives brings the decrease in stockremoving rate, the improvement in roughness and the decrease in lapping force. (5) From viewpoints of surface asperities and microstructures on lapped surfaces, the (0001) surface resembles the lead glass surface, while the (1100) surface looks like the quartz surface.
\end{abstract}

\section{1. 緒言}

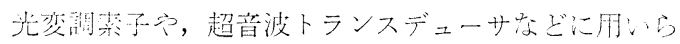
机る $\mathrm{LiNbO}_{3}$ 単結晶法かたくてもろいのだ, 精密加工に はラッビングやポリシングが適用される。しかし，この

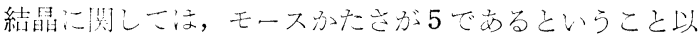
外機械的特性洨明らかでない，とくに，結晶特有の異方

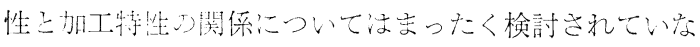
い.一力，ホシシ面の品位湔加工のラッピングによっ

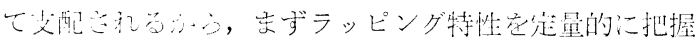

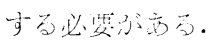

そここ，本郝で $\mathrm{LiNbO}_{3}$ のラッピングにおける結晶

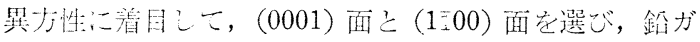

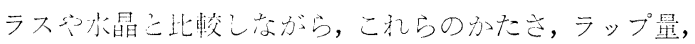
表面方ら，ラップ抵抗㧍よざラップ面の微視的構造它 檢䞑こた。

\section{2. 実験装置とその方法}

2.1 試 料

表 1 亿示声とおり，用いた試料は $\mathrm{LiNbO}_{3}$ とこれより

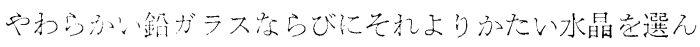

*原稿受付 昭和 44 年 8 月 12 日。昭和 43 年度精機学会春季大 会学術满演会（昭和43年 4 月 5 日）に発表.

**正会員 日本雨信電話公社 (武蔵野市緑町 3-9-11)

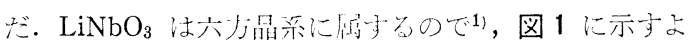

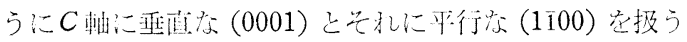

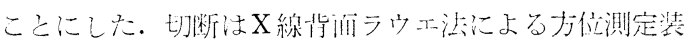
置とダイヤモンド低石以断㙨とによった。

\section{2 実験条件および加工諸量の測定法}

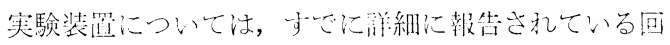

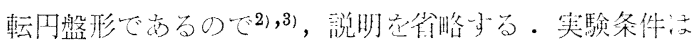

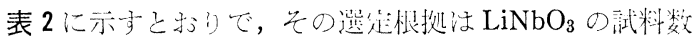
が少ないのにも多か和らダ，加工裂因が多いので，ラッ

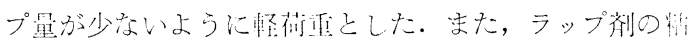

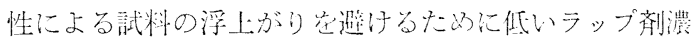
度定採用与る。

測定諸量は以下のもの忞対稚にした. (1)ラップ星：化

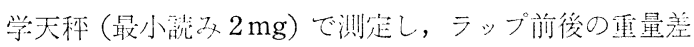

表 1 訨料の特性:

\begin{tabular}{|c|c|c|c|}
\hline 試 料 & 方位と成分 & $\begin{array}{c}\text { メープかた } \\
200 \mathrm{~g}\left(\mathrm{~kg} / \mathrm{mm}^{2}\right)\end{array}$ & 缩度 $\left(\mathrm{g} / \mathrm{cm}^{3}\right)$ \\
\hline 鉛ガラス & $\begin{array}{r}\mathrm{SiO} 54 \%, \\
\mathrm{PbO} 34 \%\end{array}$ & 420 & 3.30 \\
\hline $\begin{array}{c}\mathrm{LiNbO}_{3} \\
\text { 結 晶 }\end{array}$ & $\begin{array}{l}(0001) \\
(1 \overline{100})\end{array}$ & $\begin{array}{l}390[1120] \\
380[1010] \\
660[0001] \\
280[1120]\end{array}$ & 4.64 \\
\hline 水 晶 & $(11 \overline{2} 0)$ & 750 & 2.65 \\
\hline
\end{tabular}

試料の大きさ $11 \times 12 \times(1 \sim 2) \mathrm{mm}$

試料の個数 8 個 


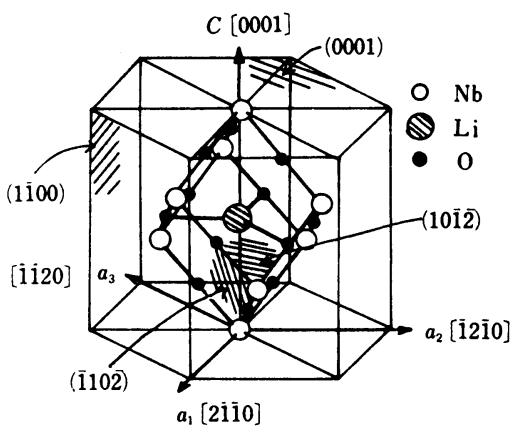

园 $1 \mathrm{LiNbO}_{3}$ の結晶構造

表 2 ラッピング条件

\begin{tabular}{|c|c|}
\hline ラップ 盤 & 回転円盤形ラップ試験機 \\
\hline ラ & 鋳 \\
\hline 回転速度 $(\mathrm{m} / \mathrm{min})$ & $25(66 \mathrm{rpm})$ \\
\hline ラップ圧力 $\left(\mathrm{g} / \mathrm{cm}^{2}\right)$ & 42. $83,125,167$ \\
\hline $\begin{array}{lr}\text { ラップ距離 } & (\mathrm{m}) \\
\text { ラップ時間 } & (\mathrm{min})\end{array}$ & $\begin{array}{c}25,75,125,175,250 \\
1,3,5,7,10\end{array}$ \\
\hline \multirow{2}{*}{ 砥 } & GC: $\# 800 \# 1500 \# 3000$ \\
\hline & WA: $\quad \# 1500 \# 3000$ \\
\hline 濃 & 砥粒：水 $=1: 3$ (重量比) \\
\hline 供 給 量 & 2 (1 回供給) \\
\hline
\end{tabular}

を密度で割って求めた. (2)表面あらさ：触針式表面あら さ測定機（触針先端半径 $5 \mu$, 縦倍率 $\times 300 \sim \times 3000$, 横 倍率 $\times 100)$ を用いた. (3)ラップ抵抗：リン青銅の片持ば ね $(50 \times 50 \times 1.5 \mathrm{~mm})$ と抵抗線ひずみゲージの組合せで 検出した，直線性は $130 \mathrm{~g}$ まで保証できるが,その感度は $7 \mathrm{~g} / \mathrm{mm}$ で多少低い. ラップ抵抗の変動が 30〜 $50 \%$ あっ たので,抵抗はその中間值とした.(4)表面観察：一部のラ ップ面の微視的構造を電子顕微鏡 $(\times 3750)$ で観察した.

\section{3. 実験結果とその考察}

\section{1 試料のかたさ}

$\mathrm{LiNbO}_{3}$ のスープかたさを $25 \mathrm{~g}$ から $500 \mathrm{~g}$ まで求め た. 印加時間は 45〜60 s で一定值に落着くものとして, $45 \mathrm{~s}$ に設定した. 図 2 に示すとおり，かたさが一定值に 近ゔく $200 \mathrm{~g}$ では, 水晶がもっともかたく, (0001) と 鉛ガラスでは約 $50 \mathrm{~kg} / \mathrm{mm}^{2}$ の差はあるが，ほとんど同 程度のかたさとみてよい. しかも（0001）において, ヌ ープ死こんの長軸を [11̄00] 方向と [1120] 方向に選ん だ場合，その差はほとんどない。これに対して，(1100） における [0001] 方向のヌープかたさは [1150] 方向の それよりもほぼ 2 倍高くなる。

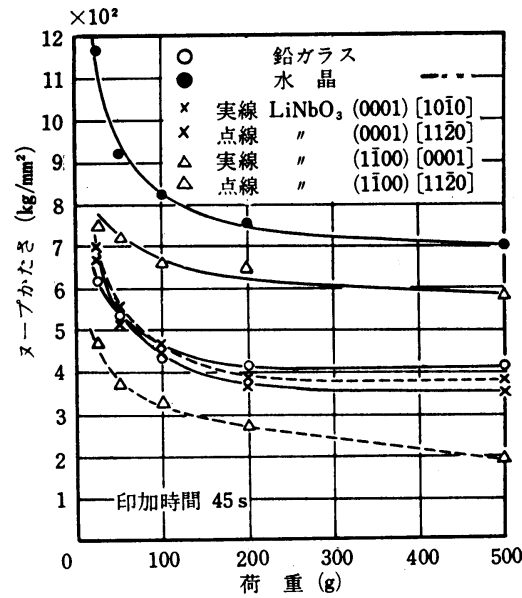

図 2 ヌープかたさの荷重依存性

一方, ヌープ圧こんの状況をみると, (0001)において は図 3 (a) の代表例に示される 形状で，われの境界は明 りょうで, [1100] 方向と [1120] 方向の差は認められな い.しかし，(1100）では同図（b)，(c) に示すように [0001] 方向と [1120] 方向とでまったく異なる. 前者の われはヌープ圧こんの短軸方向に拡がり，後者のわれは ヌープ麁こんに沿って一方向に拡がっている.

われの拡がりは概して，(1100)より（0001）のほうで 約 $20 \%$ 大きく，この面がわれやすいことを示唆する. 以上は (0001) ではへき開面 $\{1 \overline{102}\}$ が 3 回対称であるの に対し，(1100) ではへき開面が $c$ 軸には対称である が，それと直角では非対称であることによると考えられ る.したがって, $c$ 軸に関するこの異方性はラッピング 特性に顕著に現われる.

\section{2 ラップ量}

ラップ距離に対するラップ量の関係は図 4 に示すとお りで，(1100) と (0001) をくらべると, 前者には後者よ りヌープかたさで約 $25 \%$ も低い方向があるのにもかか わらず，前者のラップ量は後者のそれより少ない.これ は自由方向に転動する砥粒がへき開面に作用するさい, (0001) におけるへき開面は（1100）のそれより対称性が 高いので，前者のへき開破壊が多いためと考えられる. しかも, この傾向は図 5 に示すとおり, 粒径が大きくな ると顕著に現われる。これは粒径が大くきなると, 作用 砥粒数が減少するので, 砥粒 1 個当りの分担荷重が増し て，へき開破壊を促進するということで説明できる.

一方, $\mathrm{LiNbO}_{8}$ と水晶を比較すると, (0001) のヌープ かたさは水晶のそれの約半分であるが, ラップ量では前 者が後者の 3 倍近くもある. 一般に, 水晶ではへき開性 が弱いといわれ゙，引張破壞がおもに作用する．したが 


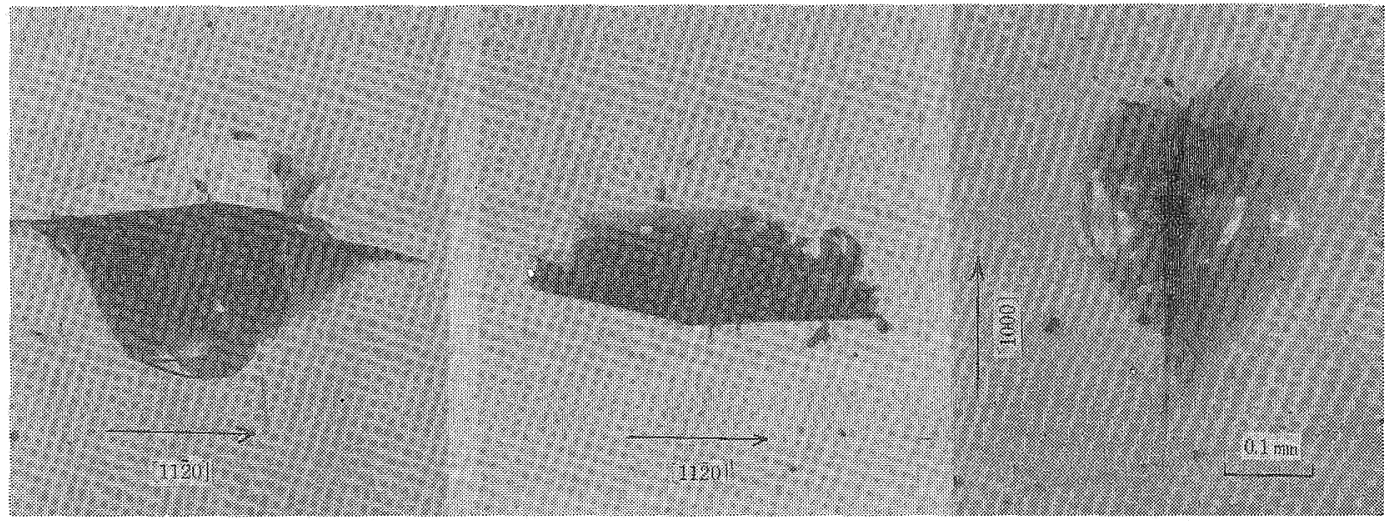

(a) (0001)

(b) (1i 00$)$

(c) (1100)

荷重 $500 \mathrm{~g}$, 印加㭙間 $45 \mathrm{~s}$

図 3 メープ压こえ
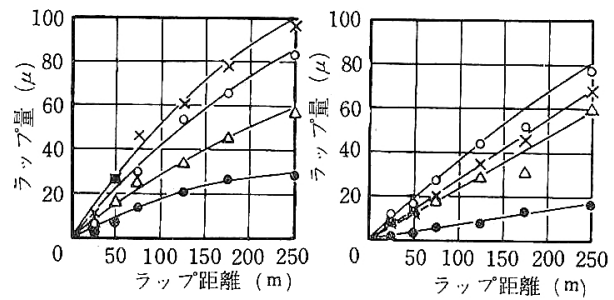

鉛ガラス, 水晶, $\times \mathrm{LiNbO}_{3}(0001)$, $\triangle \mathrm{LiNbO}_{3}(1100)$

(a) GC \#1500 による場合 (b) WA \#1500 による場合 ラップ压力 $125 \mathrm{~g} / \mathrm{cm}^{2}$, 回転速度 $25 \mathrm{~m} / \mathrm{min}$

图 4 ラップ距離とラップ量の關係

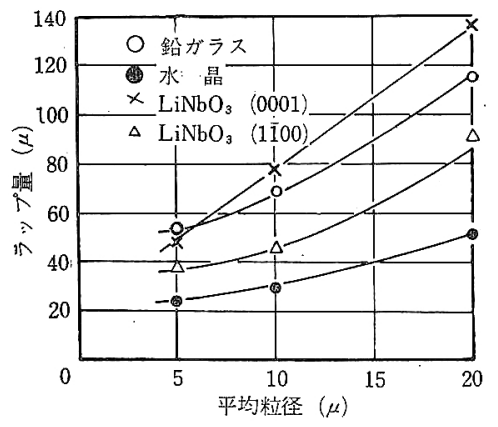

GC 低煜, ラップ压力 $125 \mathrm{~g} / \mathrm{cm}^{2}$, 回転速度 $25 \mathrm{~m} / \mathrm{min}$ ラップ距離 $125 \mathrm{~m}$

図 5 粒径とラッブ量の関係

って $\mathrm{LiNbO}_{3}$ のへき開破壞と水晶の引張破壞の养が現わ 机たものと考无ら秃るが、ラップ量には前者による作用 が，後者による作用よりはるかに效いてくる，同様に，

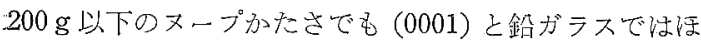
《等しいのにもかかわらず，ラップ量では前者は後者よ り約 $15 \%$ 多い，これ子へき開破壞と引張破壊の差が現
れたものといえる。

また，WA 䃨粒より加工量の多い $\mathrm{GC}$ 砥粒によるほ らが，方位の違いによ当影響怔大きい。

なお，ラップ距䧺とラップ正力のラップ量に及ぼす影 響家みると，GC 低粒の粉砕がか1500 付近よりあらいほ

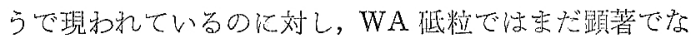

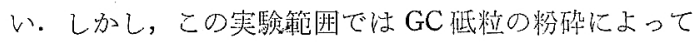
ラップ量が減少しても，WA低粒によるそれより小さく なること泳多ったた。

\section{3 ラップ面の表面あらさ}

ラップ量に示された結晶の異方性恃，図6の裴面方

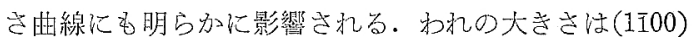

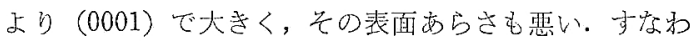

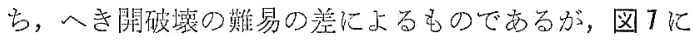
示すように，ラップ量と同じく粒径による影響が距離や 压力に比べすっと西大きい.

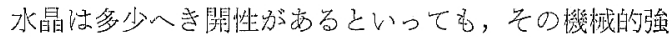
度はかたさとラップ量に示されたように，もっとも強い のだ，その表面あらさももっともよい。一方，粒径の大 きい低䊀について着目すると，(0001)の表面あらさ注

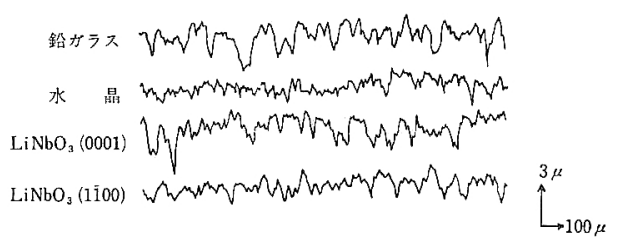

$\mathrm{GC} \# 800$, ラップ卮少 $125 \mathrm{~g} / \mathrm{cm}^{2}$ ラップ距離 $125 \mathrm{~m}$, 回転速度 $25 \mathrm{~m} / \mathrm{min}$ 図 6 表面あらさ此線の代表例 


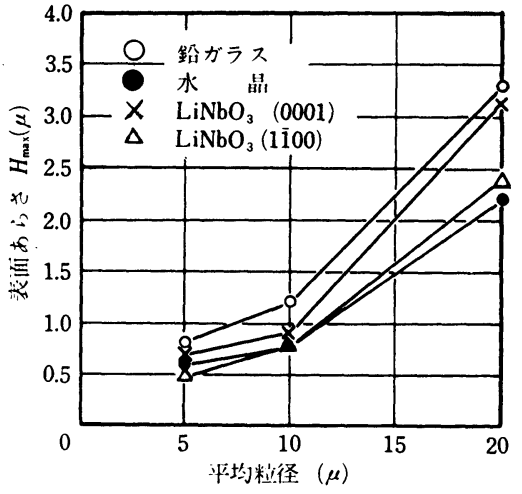

$\mathrm{GC}$ 砥粒, ラップ圧力 $125 \mathrm{~g} / \mathrm{cm}^{2}$ ラップ距離 $125 \mathrm{~m}$, 回転速度 $25 \mathrm{~m} / \mathrm{min}$ 因 7 粒径と表面あらさの関係
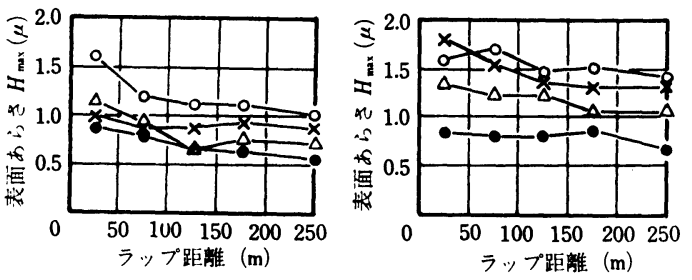

（a） GC \#1500 による場合（b）WA \#1500 による場合

○鉛ガラス, ・水晶, $\times \mathrm{LiNbO},(0001), \triangle \mathrm{LiNbO}_{3}(1 \overline{100})$

ラップ压力 $125 \mathrm{~g} / \mathrm{cm}^{2}$, 回転速度 $25 \mathrm{~m} / \mathrm{min}$

图 8 ラップ距離に対する表面あらさの推移

2 のスープかたさと図のラップ量からみて，鉛ガラスの それより大きいことが予想されるのにもかかわらず，そ の順位が逆になっている．これは $\mathrm{LiNbO}_{3}$ のへき開破壊 とガラスの引張破壞の違いによるもので, (0001) のよう にへき開面が 3 回対称をもつ場合，3方向にへき開を生 じるので, われやすい代りに，その拡がりは鉛ガラスよ り小さくなる.すなわち, われの拡がりの大小が表面あ らさの違いになったものと推定できる.

ところで, 表面あらさの向上は図 8 に示すとおりであ る. GC 砥粒と WA 砥粒によるあらさの向上程度は 0.2

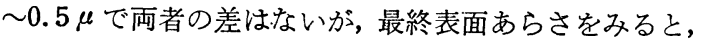
WA 砥粒では GC 砥粒の場合より約 $30 \%$ 悪い。これは WA 砥粒が GC 砥粒に比べじん性があるので, 粉砕が進 まないためによるもので，\#3000ではその差が認められ なかったが，それよりあらい われてくる.

さらに，GC 砥粒では図9に示すとおり， ラップ圧力 に対するあらさの向上程度は $0.1 \sim 0.2 \mu$ で, WA 砥粒 ではこれが認められない。これも粉砕の進行速度の大小 を示すものである.

\section{4 ラップ抵抗}

材質や異方性によるラップ抵抗の差は図 10 に示され

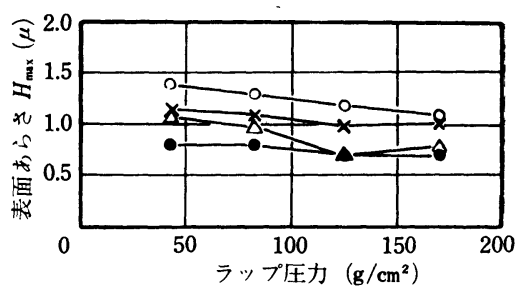

○鉛ガラス, ・水晶, $\times \mathrm{LiNbO}_{3}(0001), \triangle \mathrm{LiNbO}_{3}(1 \overline{1} 00)$ GC \#1500, ラップ距離 $125 \mathrm{~m}$, 回転速度 $25 \mathrm{~m} / \mathrm{min}$ 図 9 ラップ圧力と表面あらさの関係

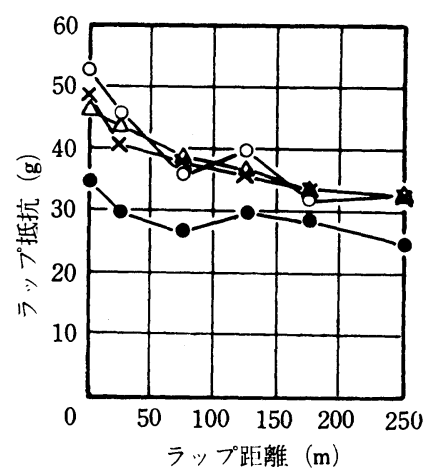

○鉛ガラス, ・水晶, $\times \mathrm{LiNbO}_{3}(0001), \triangle \mathrm{LiNbO}_{3}(1 \overline{1} 00)$ $\mathrm{GC}$ \#1500. ラップ圧力 $125 \mathrm{~g} / \mathrm{cm}$, 回転速度 $25 \mathrm{~m} / \mathrm{min}$ 図 10 ラップ距離とラップ抵抗の関係

るとおりで，水晶だけが低く，ほかは認められない。水 晶はヌープかたさからみても，もっともかたいので，砥 粒の切込み深さが浅く転動しやすい. したがって，各砥 粒についてもっともラップ抵抗が小さいといえる。しか し, ほかの試料については抵抗の変動のために, 鉛ガラ スと $\mathrm{LiNbO}_{8}$ の違い方性による抵抗の差を区別するまで に至らなかった。

また，同罒からわかるように，初期段階において GC 砥粒とWA 砥粒のいずれの場合にも，ラップ抵抗が減少 する．これは第一に，加工が進むにともなって砥粒が粉 砕され，作用砥粒数が減少する結果，砥粒と試料の接触 面積が減少するためと考えられる，第二に，ほぼ同径の 作用砥粒が均一に分布し，しかも円形でないので，初期 には作用砥粒どうしが接触し，砥粒の転動がなめらかに いかない.しかし, 加工が進むと, 試料やラップのチッ プあるいは粉砕砥粒が作用砥粒の間に入って, 砥粒の直 接接触を避けるように作用する結果, 砥粒の転動が容易 になってくるためと考えられる．抵抗の減少度合はWA 砥粒より GC 砥粒によるほうが約 $20 \%$ 大きい。これは GC 砥粒が粉砕されやすくラップ量も多いので, 上述の 作用がWA砥粒による場合より大きいことを示す.

一方，図 11 に示すとおり，粒径が小さくなるほどテ 


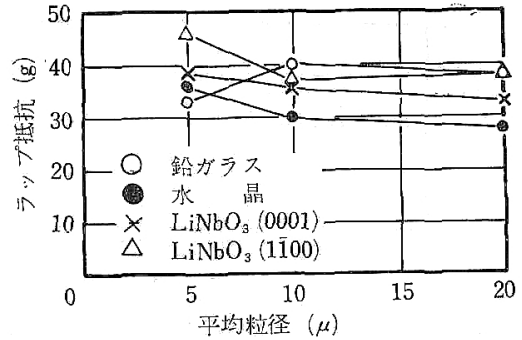

$\mathrm{GC}$ 碰粒, $テ ッ フ ゚$ 压力 $125 \mathrm{~g} / \mathrm{cm}^{2}$, 回転速度, $25 \mathrm{~m} / \mathrm{min}$, テップ距離 $225 \mathrm{~m}$

图 11 糙径とラップ抵抗の関係

ップ抵抗は大きい倾向定もつ、これ社低粒濃度が一定で あるから，粒径が小さいと作用䂠粒数が多くなって，接 触面積が増すばかりでなく，砥棓どうしの干涉によっ

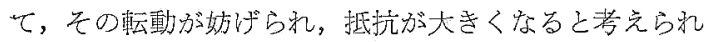
当.

\section{5 ラップ面の微視的構造}

検鏡の結果，GC 低粒とWA 砥粒の両者によるラップ 面構造注大差な放ったので，GC 砥精によるラップ面 炕加ぎって，電子顕㣲鏡によって観察した。

肃3000 で法，表面あらさに鉛ガラスは $0.8 \mu ，(0001)$

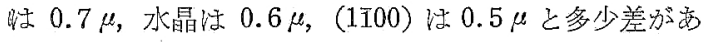
っても，観察結果では目立たない。

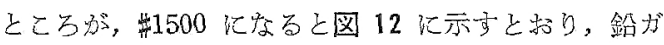
ラス上 $(0001)$ ，水晶之（100) 忹類似し，古らさ曲線

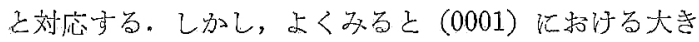

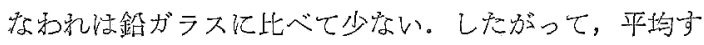
当と鉛がラスの表面あらさのほうが悪い，これからも鉛 ガラ大の引張破壊と $\mathrm{LiNbO}_{3}$ のへき開破壊の差異が認奶 られる。

一方，(0001）と（1100）を比較すると，前者には大き なわれ散在するのに坟し，後者には大きなるれがな い。卞なわち，(0001）の八き開破壞が大きいこと示 している。

\section{3. 結言}

$\mathrm{LiNbO}_{3}$ の (0001) と(1100) そついて, 鉛ガラスや 水晶と比較しながら，これらのかたさとラッピング特性 検討して，以下に要約される結論を得た。

1. スープかたさは水晶> (1100) [0001]〉鉛ガラス> (0001) > (1100)[1120]の順炕劣り，かたさとわ机の状況 汃ら $\mathrm{LiNbO}_{3}$ 江 $c$ 軸関して強い異方性があるとい并 る.

2. ラップ量は $(0001)>$ 鉛ガラス> $(1 \overline{1} 00)>$ 水晶の順 にあり，結晶の異方性に対しては粒径による影響少む。

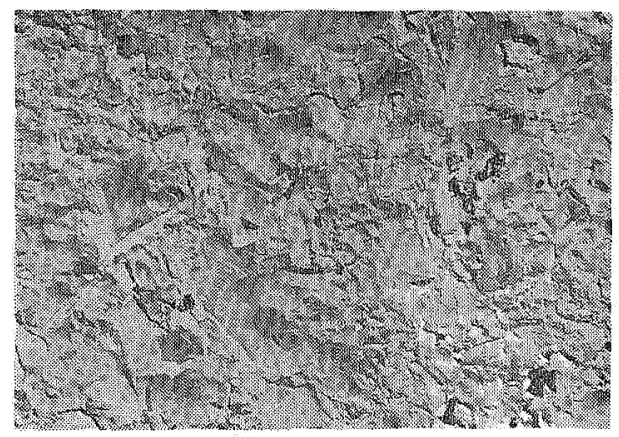

鉛 ガラス

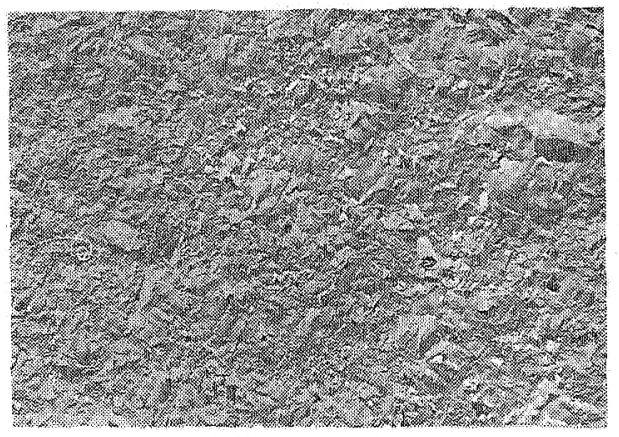

水

晶

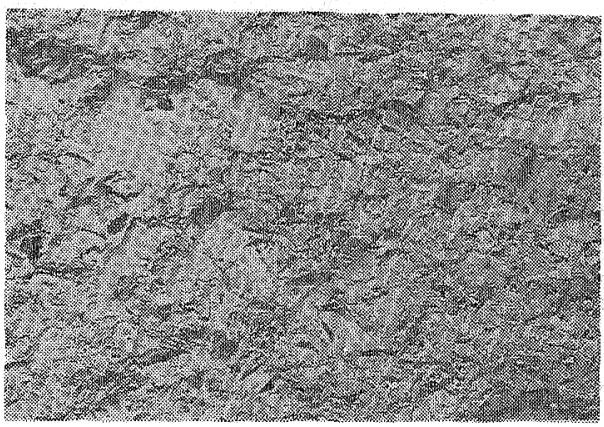

$\mathrm{LiNbO}_{3}(0001)$

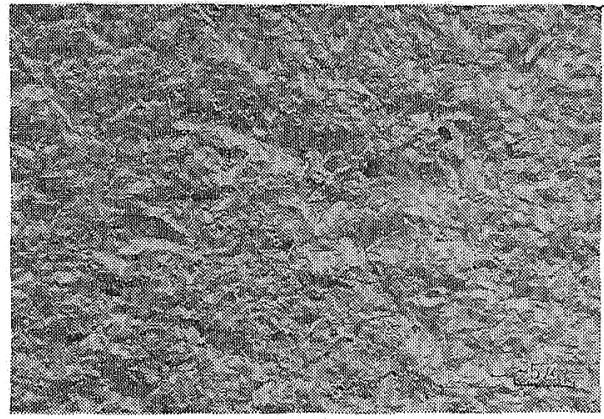

$\mathrm{LiNbO}_{3}(\overline{1} 100)$

GC \# 1500，ラップ王力 $125 \mathrm{~g} / \mathrm{cm}^{2}$ ，回䎐速度

$25 \mathrm{~m} / \mathrm{min}$ ・シップ距蜼 $125 \mathrm{~m}$

图 12 ラップ面の電䫓写真

とも大きい。 
3. 表面あらさ悎鉛ガラス> $(0001)>(1100)>$ 水晶の

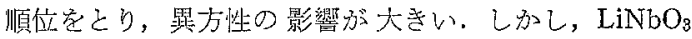
(0001) と鉛がラスのラッブ量と夜面あらさに刘忍がな

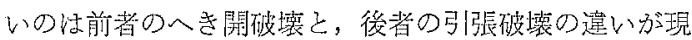
わ和当からとい光。

4. ラップ抵抗で性水晶务もっと无小さい值示した がほほかの鉛力゙ラスと $\mathrm{LiNbO}_{3}$ の造いや異方性による养

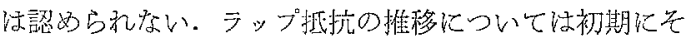
の減少定已もない，GC 佂粒にる万抵抗の減少度合怯 WA 䂠精によるそれより大きい。

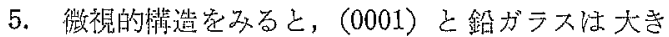
な貝がら状の和和が敞在子当点で類似する。一方， (1100) と水晶注微絧为れの発生でよく似ている。 さら

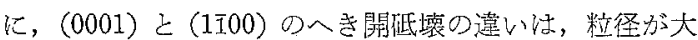
きくなる目立つ。

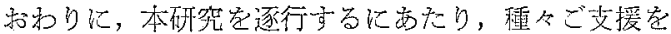

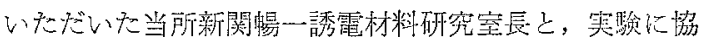
力された中島 徹氏に感謝し京亨。

\section{引用文献}

1) 新䦭瑒一: $\mathrm{LiNbO}_{3}$ の物性，忍用物垡，36，2（1967） 140.

2）井田一䬦，新止滔三，鈴木 誠，福田猫利：〕ラミックの

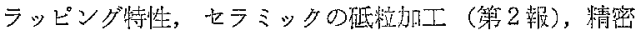
機棫，33，4 (1967) 252.

3) 井田一郎, 深瀨雅彦, 古本俊一：ジルコンチ名ン酸鉛磁器 のラッピソグ特性，精密機械，33，10（1967）640.

4) 橋本守一, 谷口紀男 (監修)：非金属材料加工技術の講座

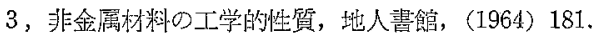

デジタル電子マイクロメータ

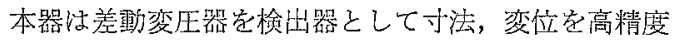
で測定し，測定值定数字で表示しまず。また出力家デジ タルプリンタ, デジタルコンパレータ，デジタル演算器 等に継ぐことによって，記録，選別，演算制御など庆䇛 汫们利用できます。

特長

○デジタル裴示で読取が容易で個人差多でません。

○最小桁 $0.1 \mu て ゙ 0 \sim 120 \mu$, 最小桁 $1 \mu$ で $0 \sim 1500 \mu$

の広籁团桨測定ができ，レンジの切换は自動です。

O主要回路はIC 学用い信頼性は高く小型です。

○二進化十進の出力定持占, 多くの応用が可能です。

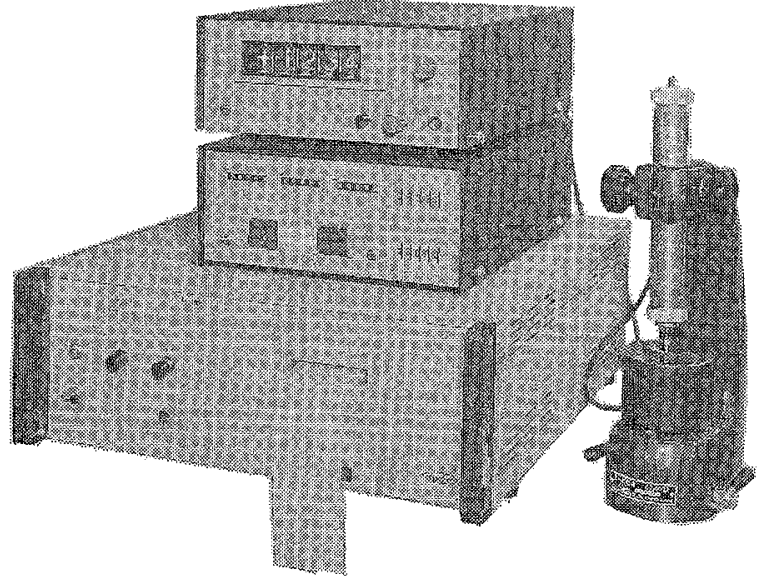

写真説明 デジタル電子マイタロメータ、デジタルュン ペレータ，デジタルプリンタの組合愔です。

\begin{tabular}{|c|c|}
\hline 表示桁数 & 4 桁表示 (スタールオーバ表示付) \\
\hline 表示方式 & 数字表示管, 極性表示土（自動） \\
\hline 表示時閒 & $0.5 \sim 3 \sec \infty$ (HOLD時) \\
\hline 計測時間 & $0.2 \mathrm{sec}$ \\
\hline 測定範娄 & $\begin{array}{l}\text { HIGH レンジ 0 } \pm 119.9 \mu \text { (最小桁 } 0.1 \mu) \\
\text { LOW レンジ } 0 \sim \pm 1499 \mu \text { (最小行 } 1 \mu \text { ) }\end{array}$ \\
\hline 度 & $\begin{array}{l}\text { HIGH レンジ } \pm 0.3 \mu \text { 以内 } \\
\text { LOW レソジ士 } \pm( \pm 0.3 \%+1 \text { digt }) \text { 以内 }\end{array}$ \\
\hline データ出力 & $1-2-4-8 \mathrm{BCD}$ \\
\hline & $100 \mathrm{~V} \pm 10 \% 50 / 60 \mathrm{~Hz} 20 \mathrm{VA}$ \\
\hline 外形寸法 & $100(\mathrm{H}) \times 240(\mathrm{~W}) \times 350(\mathrm{D})$ \\
\hline 重 & $6.5 \mathrm{~kg}$ \\
\hline
\end{tabular}

（本 社）東京都港区南麻布 4-12-20

(03) $446-1111$

(支 店)大阪市大淀区中澁本通 1-2

(06) 372-0521

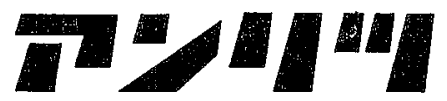

盘 安正電柔秼式會社
（名古屋）(052）582-7281

（札 幌）(0122) 26-8391

(福 岡) (092) 76-5347

(厚 木) (0462) 22-3311 